\title{
Contribution of the digestive tract microflora to amylomaize starch degradation in the rat
}

\author{
BY CLAUDE ANDRIEUX ${ }^{1}$, EMPERATRIZ DELAHAYE PACHECO ${ }^{*}$, \\ BRIGITTE BOUCHET ${ }^{2}$, DANIEL GALLANT ${ }^{2}$ AND ODETTE SZYLIT ${ }^{1}$ \\ 'INRA, CRJ 78350, Jouy en Josas, France \\ ${ }^{2} I N R A, C R$ 44072, Nantes, France
}

(Received 2 January 1991-Accepted 28 June 1991)

\begin{abstract}
To study in vivo the contribution of the bacterial flora to amylomaize starch degradation in the rat, germfree and conventional rats were fed on a diet containing either a normal maize starch or an amylomaize starch. In germ-free rats maize starch was almost totally digested in the small intestine, whereas $\mathbf{4 0} \%$ of the ingested amylomaize starch reached the caecum and $30 \%$ was excreted, despite the very high endogenous amylase activity. Study by transmission electron microscopy of germ-free caecal contents showed an endocorrosion of the starch granule. In conventional rats, as in germ-free rats, digestibility of maize starch reached $98 \%$ in the small intestine, whereas that of amylomaize starch was only $60 \%$. In the caecum of these rats amylomaize starch was fermented, and this led to a decrease in caecal $\mathrm{pH}$ and to formation of short-chain fatty acids (SCFA), especially propionate. Comparison between conventional rats fed on maize starch or amylomaize starch showed that caecal SCFA concentrations during a circadian cycle varied in the same way whereas total SCFA and lactic acid concentrations were much higher in rats fed on amylomaize starch. Amylase $(E C$ 3.2.1.1) activity was similar in the caecal contents of conventional rats whatever the ingested starch. It was lower in conventional than in germfree rats, but no starch granule remained in the caecum of conventional rats. These results showed that bacterial amylase was more efficient at degrading resistant amylomaize starch than endogenous amylase.
\end{abstract}

Starch digestion: Amylomaize starch degradation: Gut microflora: Rats

In man and in animals, appreciable proportions of starch may escape digestion in the small intestine (Stephen et al. 1983; Englyst \& Cummings, 1985; Asp et al. 1986; Berry, 1986; Flourié et al. 1986; Cummings \& Englyst, 1987). In fact, some starches such as amyloserich starch or uncooked potato starch are naturally resistant to hydrolysis by salivary and pancreatic amylases, whereas others become resistant to digestion after cooking and cooling (Englyst \& Cummings, 1985; Englyst \& Macfarlane, 1986; Ring et al. 1987, 1988).

From a nutritional point of view, the new interest devoted to these resistant starches is related to the fact that the fraction resistant to small intestinal digestion can be compared with some dietary fibres in that they possess some of the same physiological properties (Bjorck et al. 1986; Behall et al. 1989). Fermentation of poorly digestible starches, as with that of fibres, reduces the activity of bacterial enzymes such as $\beta$-glucuronidases and nitroreductases (Mallet et al. 1988) which are involved in the genesis of recto-colic cancers and in the bacterial transformations of bile acids (Andrieux et al. 1989).

The amylomaize starch studied here is a native starch containing $700 \mathrm{~g}$ amylose $/ \mathrm{kg}$. In a former study, Andrieux \& Sacquet (1986) have demonstrated that it is not totally digested by the germ-free rat, whereas it is totally degraded by the conventional rat. However, although there is a good understanding of amylomaize starch digestibility in germ-free rats,

* Present address: Universitad central de Venezuela, Maracay, Venezuela. 
the structure of resistant starch in the digestive contents is unknown. In addition, since Reddy et al. (1969) have shown large differences between germ-free and conventional rats in the amylase (EC 3.2.1.1) and maltase (EC 3.2.1.20) activities in the small intestine, the proportion of starch fermented by the microbial flora in conventional rats might be different from the fraction of starch excreted by germ-free rats.

The purposes of the present study were: (1) to estimate the respective role of digestive and bacterial enzymes in the digestion of maize and amylomaize starches in the small and large intestine of germ-free and conventional rats; (2) to compare the amylolytic activities and other glycolytic activities in germ-free and conventional rats fed on either maize starch or amylomaize starch; (3) to study the ultrastructure of amylomaize starch granules and the carbohydrate hydrolysis products in the caecum of germ-free and conventional rats.

\section{MATERIALS AND METHODS}

Animals and diets

Male Fisher 344 germ-free and conventional rats ( 3 months old, body-weight 285 (SE 5) g) were fed for 4 weeks on a semi-synthetic diet containing either $580 \mathrm{~g} / \mathrm{kg}$ of a normal maize starch (including $300 \mathrm{~g}$ amylose and $700 \mathrm{~g}$ amylopectin $/ \mathrm{kg}$ ) or an amylomaize starch (including $700 \mathrm{~g}$ amylose and $300 \mathrm{~g}$ amylopectin $/ \mathrm{kg}$ ) (Roquette frères, Lestrem, France). The other dietary ingredients were $(\mathrm{g} / \mathrm{kg}$ ) : casein 205 , maize oil 90 , cellulose 50 , minerals and vitamins 75 (Andrieux \& Sacquet, 1986).

Diets were sterilized by gamma-irradiation at $40 \mathrm{kGy}$ in vacuum-sealed plastic bags and offered ad lib. to animals as a paste containing $600 \mathrm{~g}$ demineralized water $/ \mathrm{kg}$. This paste was prepared daily at 16.00 hours.

Two groups of sixteen germ-free rats were fed on maize or amylomaize starch diets and two groups of sixteen conventional rats were fed on irradiated maize or amylomaize starch diets.

During the third week of feeding, a transit marker $\left({ }^{14} \mathrm{C}\right.$-labelled polyethylene glycol (PEG), relative molecular mass 4000$)$ was incorporated into the diets $(0.21 \mu \mathrm{Ci} / \mathrm{g})$. At the end of this period daily marker ingestion and excretion were similar and a $5 \mathrm{~d}$ balance study was conducted to measure food intake and total starch digestibility. Fresh faecal samples were collected to measure bacterial glycolytic activities. Then two rats from each group were killed every $3 \mathrm{~h}$ for $24 \mathrm{~h}$ to measure starch digestibility in the small intestine and in the hind-gut, and variations in caecal weight and caecal contents $(\mathrm{pH}$ and short-chain fatty acid (SCFA) concentrations) during the $24 \mathrm{~h}$ period.

\section{Preparation of intestinal contents and of faeces samples}

The caecal $\mathrm{pH}$ was determined under diethyl ether anaesthesia using a microelectrode. Then intestinal contents were removed immediately and portions of caecal contents were mixed with mercuric chloride for SCFA determinations or with triethanolamine buffer $(\mathrm{pH} \mathrm{7.0)}$ for lactic acid determinations. The faeces and intestinal samples were frozen in liquid nitrogen and maintained at $-20^{\circ}$ until analysed.

For ultrastructural analysis of amylomaize starch, portions of caecal contents of rats killed at 10.00 hours were immediately treated for electron microscopy analysis as described previously (Gallant et al. 1973).

\section{Analysis}

Starch digestibility at different sites in the digestive tract. The content of the last $50 \mathrm{~mm}$ of the ileum, the last $50 \mathrm{~mm}$ of the colon and the caecum of rats fed on the transit marker during the week and killed every $3 \mathrm{~h}$, were collected, washed out and the relative concentrations of starch and transit marker $\left({ }^{14} \mathrm{C}\right.$-labelled PEG) were determined. 
The ratio $(R)$, starch concentration: transit marker concentration, was measured in the intestinal contents, in faeces and in the diet. Since rats eat several meals daily and transit time is different in germ-free and conventional rats (Riottot, 1987), and because transit rate of marker and starch may be different, we computed the arithmetic mean of starch digestibility at each level of the digestive tract. The mean value of $R$ was used to calculate the mean digestibility of starch $\left(D_{S}\right)$ at different levels $(S)$ of the digestive tract (ileum, caecum, colon and faeces) for $24 \mathrm{~h} . D_{S}$ at site $S$ of the digestive tract was expressed as a percentage of intake:

$$
D_{S}=(1-R \text { site } S / R \text { in diet }) \times 100 .
$$

Starch analysis. In diets, faeces or intestinal contents, starches were dispersed in dimethylsulphoxide $(800 \mathrm{ml} / 1)$ by autoclaving for $20 \mathrm{~min}$. Samples of this suspension containing at most $5 \mathrm{~g} \mathrm{starch} / 1$ were then hydrolysed at $55^{\circ}$ for $3 \mathrm{~h}$ in a $10 \mathrm{~mm}$-phosphate buffer (pH 4.5) by amyloglucosidase (EC 3.2.1.3; Optidex 1200; Roquette fréres, Lestrem, France).

Glucose formed was determined enzymically with glucose oxidase (EC 1.1.3.4; Biotrol, Paris).

Amylase activity. This was determined using an enzymic colorimetric test with a chromophore blue as substrate (Phadebas, Pharmacia, France). Activity was expressed as $\mathrm{U} / \mathrm{g}$ fresh weight. One unit of amylase was equivalent to $1 \mu \mathrm{mol}$ maltose produced $/ \mathrm{min}$ at $37^{\circ}$.

SCFA. SCFA were determined using gas-liquid chromatography after water extraction of acidified samples. The chromatograph used was a GC 121 Del (Delsi) apparatus with a flame-ionization detector and a semi-capillary column $(15 \mathrm{~m} \times 0.53 \mathrm{~mm})$ impregnated with SP 100. Carrier gas $\left(\mathrm{N}_{2}\right)$ flow-rate was $30 \mathrm{ml} / \mathrm{min}$, column temperature $125^{\circ}$, detector temperature $155^{\circ}$, hydrogen flow-rate $40 \mathrm{ml} / \mathrm{min}$, compressed air flow-rate $40 \mathrm{ml} / \mathrm{min}$. Isobutyric acid was used as an internal standard. The integrator was a Delsi Enica 21 apparatus.

$L$ - and $D$-Lactic acids. These were determined enzymically using lactate dehydrogenase ( $E C$ 1.1.1.27; Boehringer-Mannheim).

Identification of products of starch hydrolysis in caecal contents. Carbohydrates were determined after water extraction $(1: 10, \mathrm{w} / \mathrm{v})$ and protein precipitation. Total reducing sugars were determined by the Nelson-Somogyi method (Nelson, 1944; Somogyi, 1945). Carbohydrates were separated by thin-layer chromatography on silica gel plates as described by Weber et al. (1985).

Chromatograms were developed with the following system: propanol-ethyl acetate-ethanol-acetic acid-pyridine-water $(7: 3: 3: 2: 2: 4$, by vol). Spots were revealed by heating plates sprayed with a solution of sulphuric acid in acetone $(50 \mathrm{ml} / 1)$. Glucose was determined enzymically with glucose oxidase (Biotrol, Paris).

Glycolytic activities were measured by the rate of release of $p$-nitrophenol from their $p$ nitrophenylglucosides. The reaction mixture contained $0.3 \mathrm{ml}$ substrate solution $(5 \mathrm{mM})$ and $0.2 \mathrm{ml}$ of a dilution $1: 2$ of caecal content in phosphate buffer $(0.1 \mathrm{M})$ at the caecal $\mathrm{pH}$. Incubation was at $37^{\circ}$ and p-nitrophenol concentration was measured as the optical absorbance at $400 \mathrm{~nm}$ after addition of $2.5 \mathrm{ml} 0.25 \mathrm{M}$-sodium carbonate.

\section{Statistical analysis}

Results are expressed as means with their standard errors. Values were compared by analysis of variance and the Newman-Keuls test using STAT ITCF software. 
Table 1. Nutritional variables and digestive utilization of maize and amylomaize starches in germ-free and conventional rats*

(Mean values with their standard errors for eighteen rats per group)

\begin{tabular}{|c|c|c|c|c|c|c|c|c|}
\hline \multirow{3}{*}{$\begin{array}{l}\text { Group ... } \\
\text { Starch in diet.. }\end{array}$} & \multicolumn{4}{|c|}{ Germ-free } & \multicolumn{4}{|c|}{ Conventional } \\
\hline & \multicolumn{2}{|c|}{ Maize } & \multicolumn{2}{|c|}{ Amylomaize } & \multicolumn{2}{|c|}{ Maize } & \multicolumn{2}{|c|}{ Amylomaize } \\
\hline & Mean & SE & Mean & $\mathrm{SE}$ & Mean & SE & Mean & SE \\
\hline Live wt $(\mathrm{g})$ & $316^{\mathrm{b}}$ & 7 & $300^{\mathrm{a}}$ & 5 & $322^{\mathrm{h}}$ & 6 & $297^{\mathrm{a}}$ & 8 \\
\hline Food intake $(\mathrm{g})$ & $14^{\mathrm{a}}$ & $0 \cdot 6$ & $17 \cdot 2^{b}$ & 0.4 & $14^{\mathrm{a}}$ & 1 & $14 \cdot 5^{\mathrm{a}}$ & $1 \cdot 4$ \\
\hline \multicolumn{9}{|c|}{ Digestive utilization $(\%)$ at: } \\
\hline Terminal ileum & $97 \cdot 5^{e}$ & 1.5 & $61.9^{\circ}$ & $2 \cdot 7$ & $97 \cdot 5$ & $1 \cdot 4$ & $61 \cdot 1^{c}$ & 2.5 \\
\hline Caecum & $98 \cdot 5^{\text {ef }}$ & 0.4 & $70 \cdot 4^{d}$ & $2 \cdot 5$ & $99 \cdot 7^{\mathrm{i}}$ & $0 \cdot 4$ & $96 \cdot 1^{e}$ & 0.5 \\
\hline Distal colon & $98 \cdot 5^{\text {ef }}$ & 0.2 & $71 \cdot 8^{\mathrm{d}}$ & $1 \cdot 5$ & $99 \cdot 8^{\mathrm{f}}$ & $0 \cdot 5$ & $96 \cdot 5^{\mathrm{e}}$ & $0 \cdot 6$ \\
\hline Faeces & $98 \cdot 6^{\mathrm{ef}}$ & $0 \cdot 2$ & $70 \cdot 0^{\mathrm{d}}$ & $0 \cdot 4$ & $99 \cdot 6^{\mathrm{p}}$ & $0 \cdot 1$ & $97 \cdot 1^{e}$ & $0-3$ \\
\hline
\end{tabular}

a.b For each nutritional variable, values with different superscript letters were significantly different (analysis of variance and Newman-Keuls test), $P<0.05$.

:- $-\mathrm{f}$ Values with different superscript letters were significantly different (analysis of variance and Newman-Keuls test), $P<0 \cdot 05$.

* For details of diets and procedures, see pp. 490.491.

\section{RESUL,TS}

Nutritional variables and digestive utilization of maize and amylomaize starches

The live weight of germ-free and conventional rats fed on the amylomaize starch diet was slightly lower than that of rats fed on maize starch (Table 1). Feed intake was similar in conventional rats, but in germ-free rats it was higher with the amylomaize starch diet than with the maize starch diet.

Maize starch digestion was close to $97 \%$ in the terminal ileum of germ-free and conventional rats. It was not enhanced in the caecum of germ-free rats but it was total in the caecum of conventional rats.

Amylomaize starch digestion was only $60 \%$ in the terminal ileum of germ-free and conventional rats. In the caecum of germ-free rats amylomaize starch degradation was improved, but the total digestibility remained $30 \%$ lower than that of maize starch. In the caecum of conventional rats amylomaize starch degradation was much higher than that in germ-free rats, but it remained slightly lower than maize degradation.

\section{Glycolytic activities in caecum and faeces}

Amylolytic activity (Table 2) was fourfold higher in the caecum and the faeces of germ-free rats fed on amylomaize starch than in those fed on maize starch. After centrifugation of a tenfold dilution of caecal and faecal contents, this activity was mainly fixed to insoluble particles. By contrast, in conventional rats the amylolytic activity did not vary significantly with the nature of the diet in the caecum, whereas in the faeces it was very low when rats received maize and it remained at the same level as that in the caecum of rats fed on amylomaize starch. After centrifugation of a tenfold dilution of caecal or faecal contents, $90-95 \%$ of amylolytic activity was found in the supernatant fluid.

Mucolytic activities ( $N$-acetyl- $\beta$-D-glucosaminidase (EC 3.2.1.30), $N$-acetyl- $\beta$-D-galactosaminidase ( $E C$. 3.2.1.49), $\alpha$-L-fucosidase $(E C \quad 3.2 .1 .51)$ ) were negligible in germ-free rats; $\beta$-D-galactosidase $(E C$ 3.2.1.23) and $\beta$-D-glucuronidase $(E C$ 3.2.1.31) were very low $(0.015$ (SE 0.007) and 0.006 (SE 0.0004) $\mathrm{U} / \mathrm{g}$ respectively). They were lower in 
Table 2. Glycolytic activities $(U / g)$ in caecum and faeces of germ-free and conventional rats fed on maize- or amylomaize-starch diets*

(Mean values with their standard errors for eighteen rats per group)

\begin{tabular}{|c|c|c|c|c|c|c|c|c|}
\hline \multirow{3}{*}{ Starch in diet... } & \multicolumn{4}{|c|}{ Caecum } & \multicolumn{4}{|c|}{ Faeces } \\
\hline & \multicolumn{2}{|c|}{ Maize } & \multicolumn{2}{|c|}{ Amylomaize } & \multicolumn{2}{|c|}{ Maize } & \multicolumn{2}{|c|}{ Amylomaize } \\
\hline & Mean & SE & Mean & $\mathrm{SE}$ & Mean & SE & Mean & $\mathrm{SE}$ \\
\hline & \multicolumn{8}{|c|}{ Germ-Iree } \\
\hline Amylase (EC 3.2.1.1) & \multicolumn{7}{|c|}{ Conventional } & 8 \\
\hline Amylase & $51^{\mathrm{b}}$ & 6 & $65^{\prime \prime}$ & 6 & $5^{c}$ & 3 & $55^{\mathrm{b}}$ & 5 \\
\hline $\begin{array}{c}\beta \text {-1 -glucuronidase } \\
(E C \text { B } 3.2 .1 .31)\end{array}$ & $0.88^{\prime \prime}$ & $0 \cdot 14$ & $0 \cdot 28^{\mathrm{a}}$ & 0.01 & $1.53^{d}$ & $0 \cdot 12$ & $0 \cdot 38^{b}$ & 0.06 \\
\hline $\begin{array}{c}\beta \text {-D-galactosidase } \\
(E C 3.2 .1 .23)\end{array}$ & $1.25^{\mathrm{c}}$ & 0.07 & $0 \cdot 63^{\mathrm{a}}$ & $0 \cdot 02$ & $1.45^{\mathrm{d}}$ & 0.02 & $0 \cdot 88^{\mathrm{b}}$ & 0.05 \\
\hline $\begin{array}{l}N \text {-acetyl- } \beta-\mathrm{D}- \\
\text { glucosaminidase } \\
(E C 3.2 .1 .30)\end{array}$ & $0 \cdot 70^{b}$ & 0.05 & $0 \cdot 28^{a}$ & 0.02 & $1 \cdot 2^{e}$ & $0 \cdot 1$ & $0.56^{\mathrm{b}}$ & $0 \cdot 1$ \\
\hline $\begin{array}{l}N \text {-acetyl- } \beta \text {-D- } \\
\text { galactosaminidase } \\
(E C 3.2 .1 .49)\end{array}$ & $0 \cdot 30^{\mathrm{b}}$ & $0 \cdot 04$ & $0 \cdot 16^{\mathrm{a}}$ & 0.01 & $0 \cdot 40^{\mathrm{c}}$ & 0.02 & $0 \cdot 16^{\mathrm{a}}$ & 0.01 \\
\hline $\begin{array}{c}\beta \text {-D-glucosidase } \\
(E C 3.2 .1 .21)\end{array}$ & $0.27^{a}$ & 0.01 & $0.29^{a}$ & 0.02 & $0.47^{\mathrm{h}}$ & 0.09 & $0.47^{\mathrm{b}}$ & 0.06 \\
\hline $\begin{array}{l}\alpha \text {-L-fucosidase } \\
(E C \text { E } 3.2 .1 .51)\end{array}$ & $0 \cdot 12^{\mathrm{a}}$ & $0 \cdot 01$ & $0 \cdot 11^{\mathrm{a}}$ & 0.01 & $0 \cdot 22^{\mathrm{b}}$ & 0.03 & $0 \cdot 09^{a}$ & 0.02 \\
\hline
\end{tabular}

a-r Values with different superscript letters were significantly different (Newman-Keuls test), $P<0.05$.

* For details of diets and procedures, see pp. $490-491$

caecal contents than in faeces of conventional rats (Table 2). The activity of $\beta$-Dglucuronidase was three to fourfold lower in rats fed on amylomaize starch than in rats fed on maize starch, while $N$-acetyl- $\beta$-D-glucosaminidase, $N$-acetyl- $\beta$-D-galactosaminidase and $\beta$-D-galactosidase were also lower with the amylomaize-starch diet, but $\beta$-D-glucosidase (EC 3.2.1.21) and $\alpha$-L-fucosidase were similar with the two diets.

Amylomaize starch degradation in the hind-gut of germ-free and conventional rats Ultrastructure of amylomaize starch granules. Observation of the caecal contents of germfree rats by transmission electron microscopy showed that amylomaize starch granules were partly hydrolysed, as shown by endocorrosion of the granule (Plate 1). In the conventional rat, examination of the caecal contents revealed no trace of starch granules (Plate 2).

Hydrolysis products. The caeca of germ-free rats contained 46.0 (SE 0.5 ) $\mu$ mol reducing sugars/g. These carbohydrates seem to be mostly composed of glucose (45.0 (SE $0 \cdot 2)$ $\mu \mathrm{mol} / \mathrm{g}$ ). In fact, thin-layer chromatographic analysis showed that glucose was the major hydrolysis product, followed by maltose and maltotriose, without any intermediary between long-chain malto-oligosaccharides and maltotriose. Traces of maltose and maltotriose had disappeared from the faeces of rats. The caeca of conventional rats contained $10 \mu \mathrm{mol}$ reducing sugars $/ \mathrm{g}$, of which 7.8 (SE 0.2 ) $\mu \mathrm{mol}$ was glucose. Maltose, maltotriose and short-chain malto-oligosaccharides could also be observed. The faeces of these rats contained only a small amount of maltose as shown by thin-layer chromatographic analysis. 
Table 3. Caecal variables and caecal concentrations of short-chain fatty acids (SCFA) in conventional rats fed on maize- and amylomaize-starch diets*

(Mean values with their standard errors for eighteen rats per group)

\begin{tabular}{|c|c|c|c|c|c|c|c|c|}
\hline \multirow{3}{*}{$\begin{array}{l}\text { Group ... } \\
\text { Starch in diet ... }\end{array}$} & \multicolumn{4}{|c|}{ Germ-free } & \multicolumn{4}{|c|}{ Conventional } \\
\hline & \multicolumn{2}{|c|}{ Maize } & \multicolumn{2}{|c|}{ Amylomaize } & \multicolumn{2}{|c|}{ Maize } & \multicolumn{2}{|c|}{ Amylomaize } \\
\hline & Mean & SE & Mean & $\mathrm{SE}$ & Mean & $\mathrm{SE}$ & Mean & $\mathrm{SE}$ \\
\hline $\begin{array}{l}\text { Caecal wt }(\mathrm{g} / \mathrm{kg} \\
\text { body-wt) }\end{array}$ & $54^{\prime \prime}$ & 1 & $62^{d 1}$ & 2 & $13^{\mathrm{a}}$ & 1 & $34^{\prime \prime}$ & 2 \\
\hline $\mathrm{pH}$ & $7 \cdot 0$ & 0.1 & $7 \cdot 1^{\prime \prime}$ & $0 \cdot 1$ & $6 \cdot 75^{b}$ & 0.02 & $5 \cdot 8^{\mathfrak{a}}$ & $0 \cdot 1$ \\
\hline $\mathrm{SCFA}(\mu \mathrm{mol} / \mathrm{g})$ & $0 \cdot 2^{a}$ & $0 \cdot 1$ & $0 \cdot 2^{\mathrm{at}}$ & $0 \cdot 1$ & $48^{11}$ & 5 & $77^{\circ}$ & 4 \\
\hline $\begin{array}{l}\text { Total SCFA } \\
(\mu \mathrm{mol})\end{array}$ & $1 \cdot 1^{a}$ & $0 \cdot 1$ & $1 \cdot 2^{\mathrm{a}}$ & $0 \cdot 1$ & $200^{\mathrm{b}}$ & 12 & $700^{\circ}$ & 33 \\
\hline
\end{tabular}

a d Values with different superscript letters were significantly different (Newman-Keuls test), $P<0 \cdot 05$.

* For details of diets and procedurcs, see pp. $490-491$.

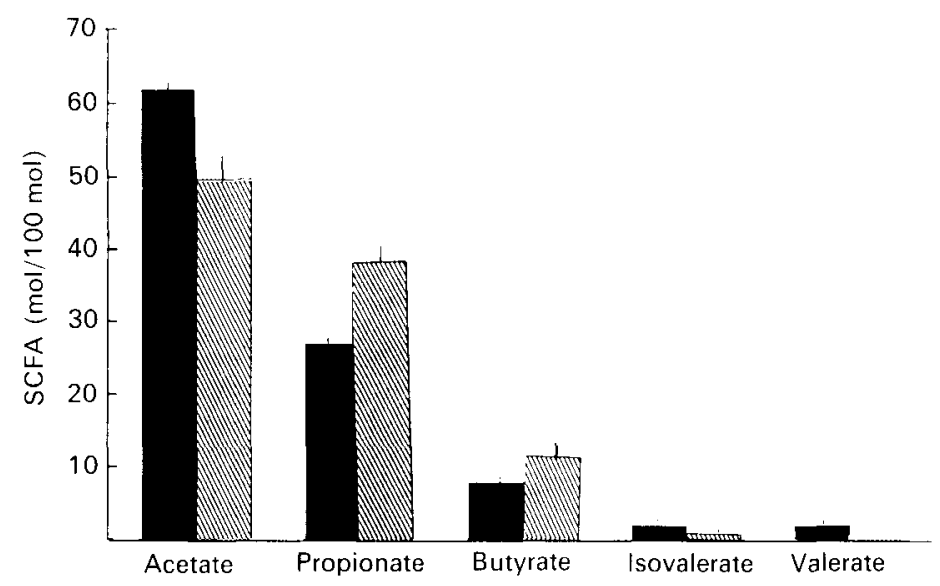

Fig. 1. Relative concentrations (mol/100 mol) of the different short-chain fatty acids (SCFA) in caecal contents of conventional rats fed on a maize-starch diet $(\boldsymbol{D})$ or an amylomaize-starch diet $(\mathbb{\Xi})$. Values are means with their standard errors represented by vertical lines for eighteen rats per group. For details of diets and procedures, see pp. $490-491$.

Fermentation of starches in conventional rats

Caecal variables and caecal SCFA concentrations (Table 3). In germ-free rats caeca were enlarged: $5 \cdot 4$ (SE $0 \cdot 1) \%$ of live weight when feeding was based on maize starch and 6.2 (SE) $0.2) \%$ when it was based on amylomaize starch, which corresponds to a weight increase of $25 \%$. The caecal $\mathrm{pH}$ of these rats was neutral and the caecum contained only traces of acetate. In conventional rats, compared with maize, amylomaize starch caused a $300 \%$ increase in caecal weight and a significant reduction in intestinal $\mathrm{pH}$. The caecal SCFA concentration increased significantly and the total amount of SCFA was increased 3.5-fold. The relative concentrations of the different SCFA were considerably modified by amylomaize ingestion (Fig. 1). The mean concentration of acetate was reduced by one-third with corresponding increases in propionate and to a less extent in butyrate; that of valerate, already very low, decreased still further or disappeared. 

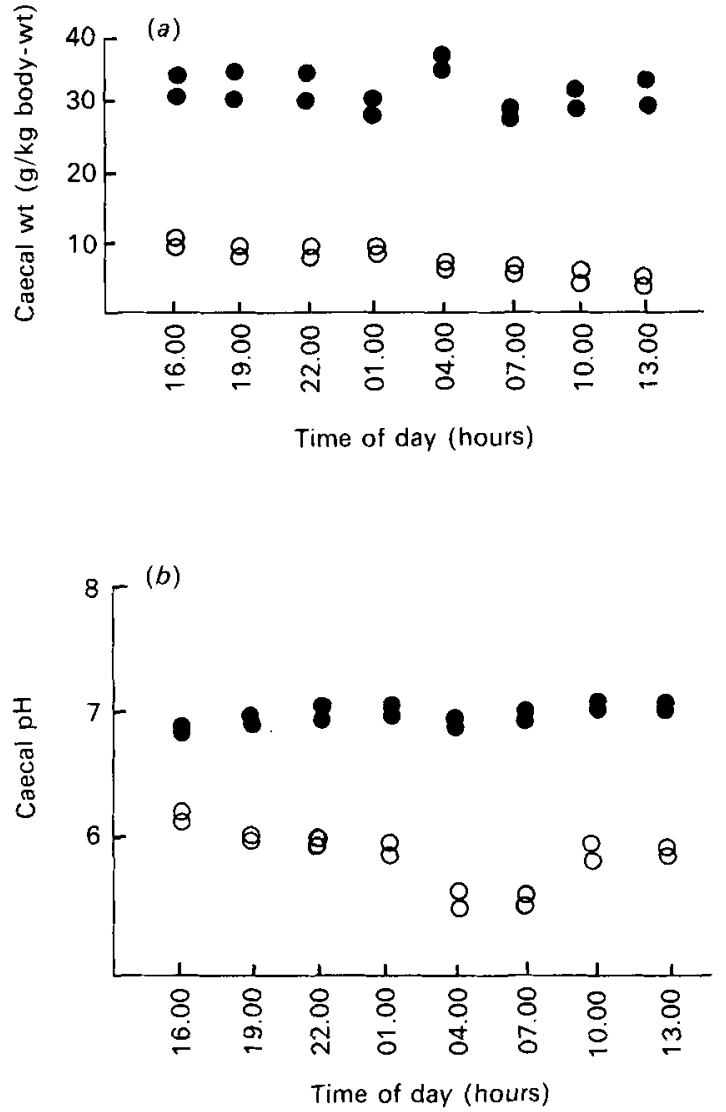

Fig. 2. Circadian variation in (a) the caecal weight and $(b)$ caecal $\mathrm{pH}$ in conventional rats fed on a maize-starch diet $(O)$ or an amylomaize-starch diet $(O)$; each value corresponds to one rat. For details of diets and procedures, see pp. $490-491$.

Circadian variation in the caecal weight, $p H, S C F A$ and lactic acid concentrations. In conventional rats individual values for caecal variables showed that caecal weight was always higher in rats fed on amylomaize starch than in those fed on normal starch (Fig. $2(a)$ ). The caecal $\mathrm{pH}$ was always lower in rats fed on amylomaize starch, with a more marked decrease between 04.00 and 13.00 hours (Fig. 2(b)). Total lactic acid concentration ( $\mathrm{L}$ - and D-lactic acid) was very low in rats fed on maize starch; it was higher at every timepoint in rats fed on amylomaize starch with a maximum at 04.00 hours (Fig. 3(a)) without change of the L-:D-lactic acid ratio (1.8 (SE 0.1)). Variations in caecal SCFA concentrations were similar in rats fed on the two types of starches (Fig. 3(b)). At 16.00 hours, before the diets were given to the rats, this concentration was at a minimum. During the feeding period (16.00-07.00 hours) the caecal SCFA concentration increased progressively to reach a maximum value almost twice as high as the initial value. The circadian variation in the total amount of SCFA in the caecum exhibited much more marked differences between the two types of starch. With maize the variation was small, the maximum values being observed between 04.00 and 10.00 hours. With amylomaize it increased considerably (Fig. $3(c)$ ). 

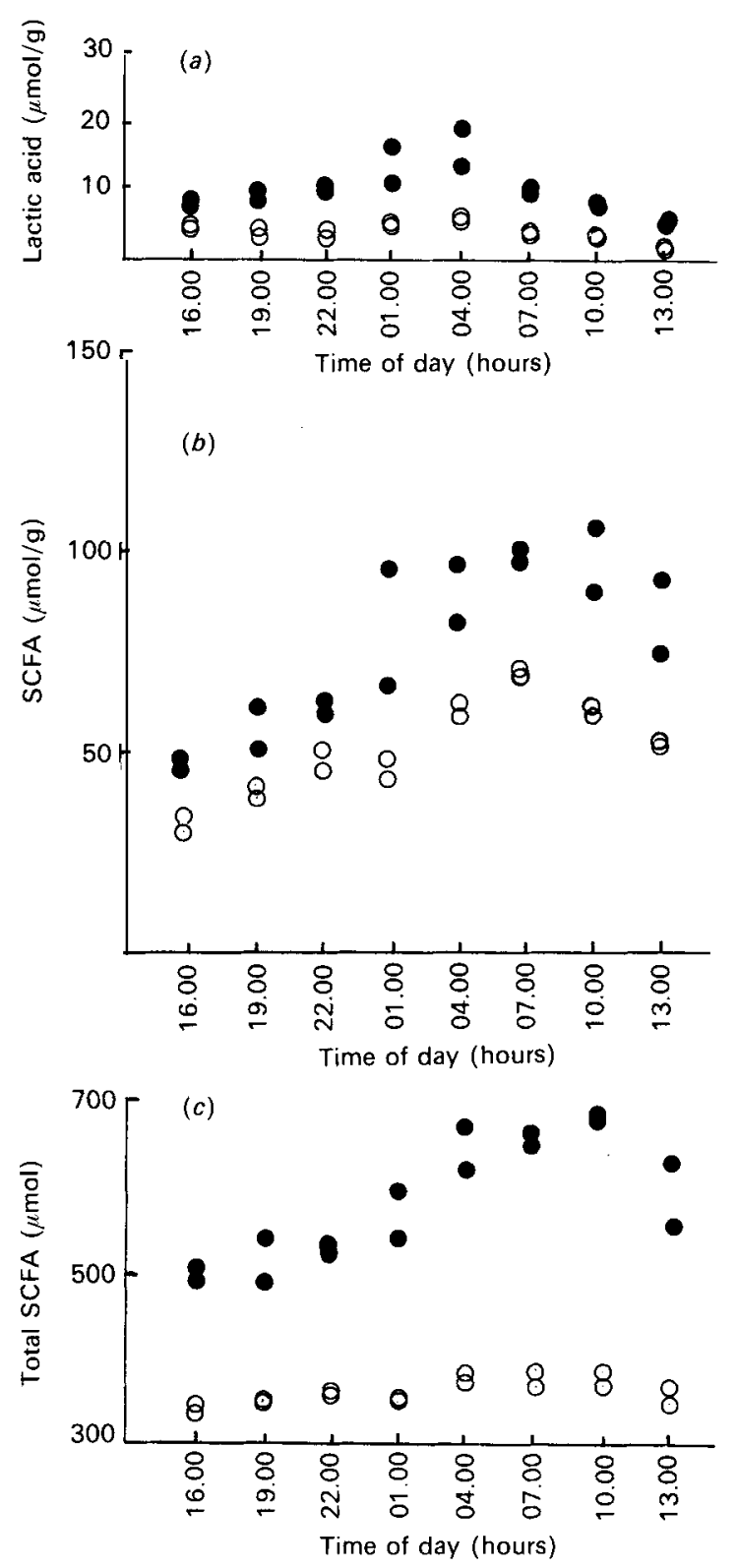

Fig. 3. Circadian variation in (a) lactic acid and $(b)$ short-chain fatty acid (SCFA) caecal concentrations, and $(c)$ total amount of SCFA in the caecum of conventional rats fed on a maize-starch diet $(O)$ or an amylomaize-starch diet $(\bigcirc)$; each value corresponds to one rat. For details of diets and procedures, see pp. $490-491$.

\section{DISCUSSION}

These results show that ingestion of amylomaize starch modifies the digestive physiology of rats. Differences between germ-free and conventional rats show the contribution of the microflora to amylomaize degradation in the hind-gut. They confirm some published data such as the slightly depressive effect of amylomaize on growth (Ayano et al. 1977; Sacquet et al. 1983), increased feed intake in the germ-free rat (Andrieux \& Sacquet, 1986) or the resistance of amylose-rich starches to hydrolysis by salivary and pancreatic amylases 
observed in animals (Szylit et al. 1974; Ayano et al. 1977) and in man (Stephen et al. 1983; Englyst \& Cummings, 1985; Asp et al. 1986; Berry, 1986; Cummings \& Englyst, 1987).

The crystalline structure of these starches, and particularly that of amylose, may be responsible for this resistance to hydrolysis by endogenous amylases (Ring et al. 1988; Sievert \& Pomeranz, 1989), resulting in the small intestine in a slower hydrolysis of amylose into glucose and in a delayed postprandial insulin response (Thorne et al. 1983; Goddard et al. 1984; Behall et al. 1989).

We have described starch digestion in different parts of the digestive tract and shown that the microbial flora does not affect starch digestion in the small intestine. However, Reddy et al. (1969) observed a halving of the amylase concentration in the intestinal lumen and the maltase content of the enterocyte in the conventional rat compared with the germ-free rat.

Our results show that amylomaize starch granules are partly hydrolysed when entering the caecum. They present an endocorrosion similar to that observed by Gallant et al. (1973) after enzymic attack by pig pancreatic enzyme.

In germ-free rats, feeding on amylomaize starch compared with maize starch led to a higher amylase activity in the hind-gut. However, in these rats the degradation of amylomaize starch granules by the digestive enzymes is probably very slow, since even after a transit time of several days in the large intestine (Riottot, 1987), 30\% of starch is not digested and is excreted. In germ-free rats, amylase activity was similar in the faeces and in the caecum, whatever the ingested starch, and it was mainly fixed to starch granules. By contrast, in conventional rats this activity is mainly free in the supernatant fraction, as observed by Macfarlane \& Englyst (1986) in human faeces. However, these authors showed that bacteria-bound activity was considerably more efficient in breaking down starch, and that amylolytic bacteria belonging to the genera Bifidobacterium, Bacteroides, Fusibacterium and Butyrivibrio can play a major role in hydrolysis of starch in the colon.

There was no difference between the amylase activity in the caeca of conventional rats fed on maize or amylomaize starch. If this activity remained unchanged in the faeces of rats fed on amylomaize starch, it was almost zero in the faeces of rats fed on normal maize starch. These results are in agreement with those of Reddy et al. (1969), who showed that the intestinal flora inactivates endogenous enzymes. The persistence of a higher amylase activity in conventional rats fed on amylomaize starch suggests that the activity of bacterial proteases may be inhibited or reduced by this starch, either because these amylases are protected by their substrate (Rosenblum et al. 1988), or because the production of proteolytic enzymes is lower in these rats. The decreased proportion of isovalerate, a metabolite produced by bacterial proteolysis (Prins, 1977), supports this hypothesis. Mallet et al. (1988) have also demonstrated a reduced activity of azo- and nitro-reductases in conventional rats fed on partly resistant starches such as amylomaize.

Our results confirm that amylomaize starch fermentation in the large intestine of the conventional rat considerably modifies bacterial activity and the bacterial ecosystem (Mallet et al. 1988; Andrieux et al. 1989). The $\mathrm{pH}$ decrease and the quantitative and qualitative variations in the SCFA may indicate a change in the equilibrium of bacterial populations. Indeed, conventional rats fed on amylomaize for 3 months then isolated from any bacterial contamination except their own microbial flora and again fed on normal maize starch do not recover their initial bacterial activity (Andrieux et al. 1989).

The kinetic study of variations in $\mathrm{pH}$ and SCFA caecal concentrations showed that intestinal fermentation induces changes in the intestinal environment between the fasting and digestion periods. In rats fed on maize starch these changes only affected the SCFA levels, but the $\mathrm{pH}$ remained stable. In rats fed on amylomaize starch both the $\mathrm{pH}$ and the SCFA varied. In these rats the increase in the caecal volume probably led to a better 
absorption of SCFA by enhancing the absorption surface of the caecum and by lengthening the duration of intestinal transit (Riottot, 1987). However, circadian variations in the caecal environment may lead to the disappearance of some bacterial populations sensitive to variations in the environment, such as the $\mathrm{pH}$ decrease, to the benefit of amylolytic bacteria capable of degrading the resistant starch. It may be interesting to isolate these bacteria and to study their metabolism in gnotoxenic rats.

\section{REFERENCES}

Andrieux, C., Gadelle, D., Leprince, C. \& Sacquet, E. (1989). Effects of some poorly digestible carbohydrates on bile acid bacteria transformations in the rat. British Journal of Nutrition 62, 103-119.

Andrieux, C. \& Sacquet, E. (1986). Effect of amylomaize starch on mineral metabolism in the adult rat: role of the microflora. Journal of Nutrition 116, 991-998.

Asp, N. G., Bjorck, I., Holm, J., Nyman, M. \& Siljestrom, M. (1986). Enzyme resistant starch rations and dietary fibre. Scandinavian Journal of Gastroenterology 129, Suppl. 29-35.

Ayano, Y., Furuhashi, T, Watanabe, Y., Suzuki, T. \& Takai, Y. (1977). On the in vitro digestion of raw amylomaize VII starch and on the growth of weaning rats fed the starch as a sole carbohydrate source. Journal of the Japanese Society of Food and Nutrition 30, 123-130.

Behall, K. M., Sholfield, D. J., Yuhaniak, I. \& Canary, J. (1989). Diets containing high amylose vs amylopectin starch: Effects on metabolic variables in human subjects. American Journal of Clinical Nutrition 49, 337-344.

Berry, C. S. (1986). Resistant starch formation and measurement of starch that survives exhaustive digestion with amylolytic enzymes during the determination of dietary fibre. Journal of Cereal Science 4, 301-314.

Bjorck, I., Nyman, M., Pederson, B., Siljestrom, M., Asp, N. G. \& Eggum, B. O. (1986). On the digestibility of starch in wheat bread studies in vitro and in vivo. Journal of Cereal Science 4, 1-11.

Cummings, J. H. \& Englyst, H. N. (1987). Fermentation in the human large intestine and the available substrates. American Journal of Clinical Nutrition 45, 1243-1255.

Englyst, H. N. \& Cummings, J. H. (1985). Digestion of the polysaccharides of some cereal foods in the human small intestine. American Journal of Clinical Nutrition 42, 778-787.

Englyst, H. N. \& Macfarlane, G. T. (1986). Breakdown of resistant and readily digestible starch by human gut bacteria. Journal of the Science of Food and Agriculture 37, 699-706.

Flourié, B., Florent, C., Jouany, J. P., Thivend, P., Etanchaud, F. \& Rambaud, J. C. (1986). Colonic metabolism of wheat starch in healthy humans: effects of fecal outputs and clinical symptoms. Gastroenterology 90 , $111 \sim 119$.

Gallant, D. J., Derrien, A., Aumaitre, A. \& Guilbot, A. (1973). Dégradation in vitro de l'amidon par le suc pancréatic. Etude par microscopie électronique à transmission et à balayage. (In vitro degradation of starch by pancreatic juice. Studies by transmission and scanning electron microscopy.) Starch-Starke 2, 56-64.

Goddard, M. S., Young, G. \& Marcus, R. (1984). The effect of amylose content on insulin and glucose responses to ingested rice. American Journal of Clinical Nutrition 39, 388-392.

Macfarlane, G. T. \& Englyst, H. N. (1986). Starch utilization by the human large intestinal microflora. Journal of Applied Bacteriology 60, 195-201.

Mallet, A. K., Bearne, P. J., Young, P. J., Rowland, D. \& Berry, C. (1988). Influence of starches of low digestibility on the rat caecal microflora. British Journal of Nutrition 60, 597-604.

Nelson, N. (1944). A photometric adaptation of the Somogyi method for the determination of glucose. Journal of Biological Chemistry 153, 375-380.

Prins, R. A. (1977). Biochemical activities of gut microorganisms. In The Normal Flora of the Gut, pp. 73-183 [R. T. J. Clark and T. Bauchop, editors]. London and New York: Academic Press.

Reddy, B. S., Pleasants, J. R. \& Wostman, B. S. (1969). Pancreatic enzymes in germ free and conventional rats fed chemically defined, water soluble diet free from natural substrates. Journal of Nutrition 97, 327-334.

Ring, S. G., Colonna, P., Miles, M. J., Morris, V. J. \& Turner, R. (1987). Spherulitic crystallization of short chain amylose. International Journal of Biological Macromolecules 9, 158-160.

Ring, S. G., Gee, J. M., Whitman, M., Orford, P. \& Johnson, I. T. (1988). Resistant starch : Its chemical form in foodstuffs and effect on digestibility in vitro. Food Chemistry 28, 97-109.

Riottot, M. (1987). Métabolisme des acides biliaires chez le rat. Influence de la flore microbienne du tractus digestif et des glucides alimentaires. (Bile acid metabolism in the rat. Effect of intestinal microflora and dietary carbohydrates.) Thèse de Doctorat d'état, Orsay.

Rosenblum, J., Irwin, E. \& Alpers, D. (1988). The role of salivary amylase protection in digestion. Gastroenterology 95, 1422-1431.

Sacquet, E., Leprince, C. \& Riottot, M. (1983). Effects of amylomaize starch on cholesterol and bile acid metabolisms in germ-free (axenic) and conventional (holoxenic) rats. Reproduction, Nutrition, Développement 23, 783-792.

Sievert, D. \& Pomeranz, Y. (1989). Enzyme-resistant starch I. Characterization and evaluation by enzymatic, thermoanalytical and microscopic methods. Cereal Chemistry 66, 342-347. 


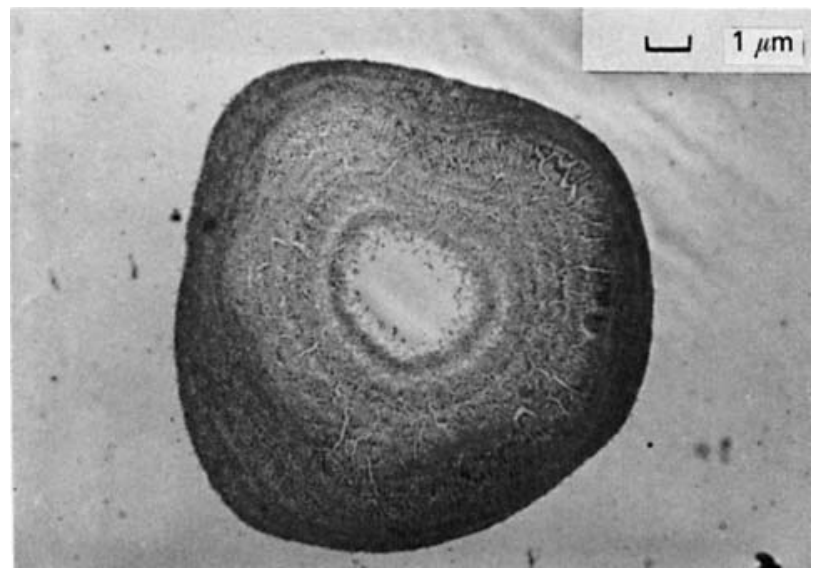




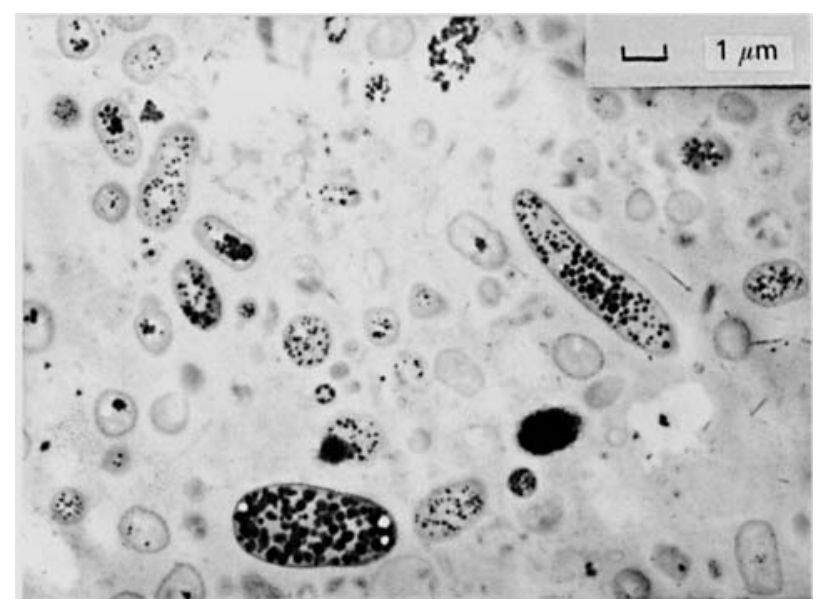


Somogyi, M. (1945). A new reagent for the determination of sugars. Journal of Biological Chemistry 160, 61-73. Stephen, A. M., Haddad, A. C. \& Phillip, S. F. (1983). Passage of carbohydrate into the colon. Direct measurements of humans. Gastroenterology 85, 589-595.

Szylit, O., Delort-Laval, J. \& Borgida, L. P. (1974). Dégradation dans le jabot du coq et efficacité d'amidons de mais à différents taux d'amylose sur la croissance du poulet. (Degradation in the chicken crop and the effect of starches of different amylose contents on chicken growth.) Annales de Zootechnie 23, 253-261.

Thorne, M. J., Thompson, L. U. \& Jenkins, D. J. A. (1983). Factors affecting starch digestibility and the glycemic response with special reference to legumes. American Journal of Clinical Nutrition 38, 481-488.

Weber, M., Darzens, D., Coulombel, C., Foglietti, M. J. \& Chararas, C. (1985). Purification and some properties of two amylases from Phoracanta semipuncta larvae. Comparative Biochemistry and Physiology 80 B, 57-60.

\section{EXPLANATION OF PLATES}

Plate 1. Amylomaize starch granule in the caecum of germ-free rats fed on an amylomaize-starch diet. $\times 5000$.

Plate 2. Caecal content of conventional rats fed on an amylomaize-starch diet. $\times 5000$. 